\title{
Stability of pillar between two caverns with dyke intrusion: A case study
}

\author{
P Nareen, M Mahalakshmi, S Shasank, K John and B Abhishek \\ L\&T Construction Company Ltd. \\ Chennai, India \\ pnkr@Intecc.com
}

\begin{abstract}
This paper presents numerical analyses for the stability of a pillar between two caverns in an underground oil storage project. The geological condition of this pillar reveals two major lineaments (intrusive bodies) intersecting each other between two caverns, which results in dislocation of dykes and poor rock condition. Empirical and numerical approaches were used and compared in this study focusing on tunnel safety. Rock mass at the site was characterized using empirical method namely Rockmass Quality $Q$. The $Q$ values were determined by using field data and the mechanical properties of intact rock samples were evaluated in the laboratory. The support systems were analyzed using software based on Finite Difference Method (FDM) method. The support requirements were proposed accordingly in terms of different rock mass classification systems. Four cross sections along the longitudinal profile with shifting of dyke locations were selected and analyzed. The analyses were carried out in FLAC 2D to study stress changes, deformation around cavern openings. The interfaces between the parent rock mass (Granitic Gneiss) and dyke (Dolerite) has taken onto account and modelled in order to analyze the interaction and the stability of the pillar between the two caverns.
\end{abstract}

Keywords: Cavern; Dyke; Pillar; Support; FLAC 2D and Insitu stress

\section{I.INTRODUCTION}

The underground storage alternatives are strategically secure, space saving, economic and optimal option in comparison to the surface storage facilities. However, construction underground poses significant challenges in terms of varying geological conditions, groundwater and intrinsic properties of rock mass. According to these conditions, the rock mass support system for these caverns arrived at based on various empirical, semi empirical and numerical modeling approaches. The empirical approaches lack the information of stress distribution, deformations and interaction between various geometric and geological bodies. The aspects are well obtained from numerical simulations. Similarly, numerical modeling can be finetuned for various ground classes as well as in-situ conditions at the site. For the stability of tunnel, both factor of safety and the displacements that rock mass, which may influence the service of the structure, should be addressed with due emphasis.

The case study discussed in this paper is an underground cavern used for material storage to facilitate the future needs. The geological appraisal of these caverns reveal that the excavation was largely cut across the parent rock and dykes in between. These caverns had maximum overburden of 100- $120 \mathrm{~m}$ above the roof. The geometric section of two caverns is same which is shown in Fig. 1. The span of caverns is $20 \mathrm{~m}$ and separated by the distance of $30 \mathrm{~m}$ by a pillar.

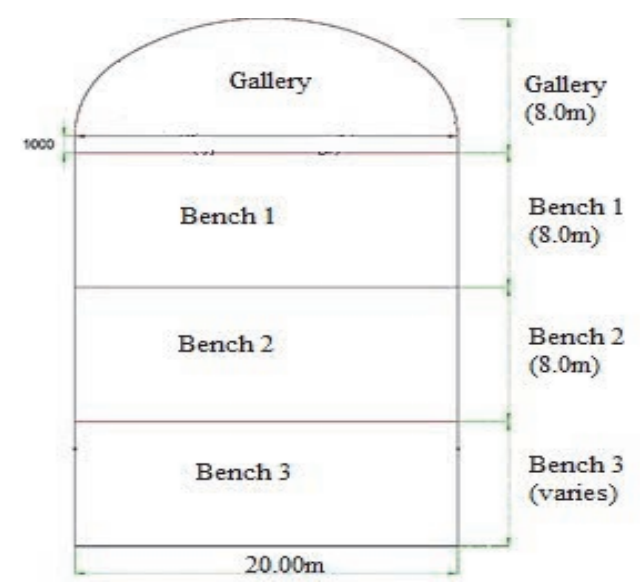

Fig. 1. Geometric details of the cavern

The storage caverns were typically $30 \mathrm{~m}$ height and excavated in 4 stages, namely gallery and three benches. Bench 1, Bench 2 is $8 \mathrm{~m}$ height each and Bench 3 with varying height geometric section of cavern was tabulated in Table I. Sections A-A, B-B, C-C and D-D which are shown in Fig. 3.

TABLE I. GEOMETRIC CHARACTERISTICS OF CAVERN

\begin{tabular}{|c|c|c|}
\hline Section & Cavern 1 (bench-3) (m) & Cavern 2 (bench-3) (m) \\
\hline A-A & 3.85 & 5.55 \\
\hline B-B & 3.90 & 5.49 \\
\hline C-C & 3.96 & 5.41 \\
\hline D-D & 4.16 & 5.32 \\
\hline
\end{tabular}

\section{GEOLOGICAL AND GEOTECHNICAL STUDIES}

Large storage caverns are ideally located at technical suitable sites. Because of the high capital costs and the risks associated with public access to these facilities, care has to be taken in the design of the caverns to ensure that potential risks are kept to an absolute minimum, while, at the same 
time, providing cost effective and practical engineering solutions. In this context, engineering geology plays an important role in planning, design and construction of underground rock cavern storage facility. In this case study, the rock type is basically granitic gneiss, with granite zones and local banding (gneissic structure) with alternation of mafic bands (predominant dark minerals) and felsic minerals (predominant light minerals). A few thin mafic dykes were observed in the local quarries. The laterite was covering the bedrock everywhere, with a thickness higher than 8 meters on the plateau and locally less on the slopes, due to erosion. From geological investigations, four dolerite bodies were found to be intruding the parent rock formation in the form of a dyke. Out of these four, two intrusive bodies intersected each other at pillar location (between the two caverns). This study concentrates on intersection in the pillar zone between two caverns wherein dyke intrusions are present. The location and properties of dyke intrusion was observed from the geological profile. The major geological structure (mafic dyke) of $20 \mathrm{~m}$ with hydrothermal alteration zone and its orientation with tunnel alignment was observed from the geological mapping. The presence of this major dyke could impact the cavern stability. This dyke was considered one of the risky zones in excavation. The location, orientation with cavern layout and properties of dyke has been derived from the field observations. Rock mass characterization has been done by $Q$ value index. The general strike of foliation in the gneiss was found to have trend of E-W with $75^{\circ} \sim 88^{\circ}$ northerly dipping. The predominant joint sets were given in Table II.

The dyke boundary was sharp and fractured. At contact with parent rock, it was found to be fresh and fractured in general but at some places, sandy silt particles were found in the contact. Very little amount of water was encountered in this region. Dyke and fracture zone together constituting of about 50-60m thick was supposed to be critical zone during construction shown in Fig. 2.

TABle II. PREDOMinANT JoINT SETS

\begin{tabular}{|l|l|l|l|}
\hline Description & $\begin{array}{l}\text { Joint } \\
\text { No. }\end{array}$ & $\begin{array}{l}\text { Dip angle / Dip } \\
\text { Direction }\end{array}$ & Strike /Dip \\
\hline \multirow{2}{*}{ Vertical Joint Set } & J1-1 & $82 / 251$ & N19W/82SW \\
\cline { 2 - 4 } & J1-2 & $83 / 075$ & N15W/NE \\
\hline \multirow{2}{*}{$\begin{array}{l}\text { Horizontal } \\
\text { Joint set }\end{array}$} & J2-1 & $12 / 180$ & N90W/13SW \\
\cline { 2 - 4 } & J2-2 & $13 / 008$ & N82W/13NE \\
\hline Vertical Joint set & J3 & $79 / 279$ & N09E/79NW \\
\hline
\end{tabular}

Shifting and disorientation of intrusive bodies has observed during excavation sequence of heading portion. Shifting results in the formation numerous dyke swarms which oriented semi-parallel to cavern alignment. The probe hole test results showed that these dykes were extended up to a distance of $10 \mathrm{~m}$ behind the storage cavern wall. In addition, these branched dyke rocks were highly irregular and discontinuous. Fig. 2 shows the plan view of

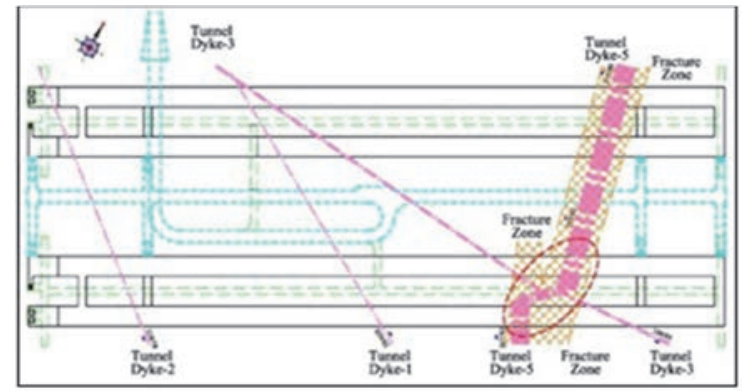

Fig. 2. Intersection and shifting of dyke in pillar zone between two caverns

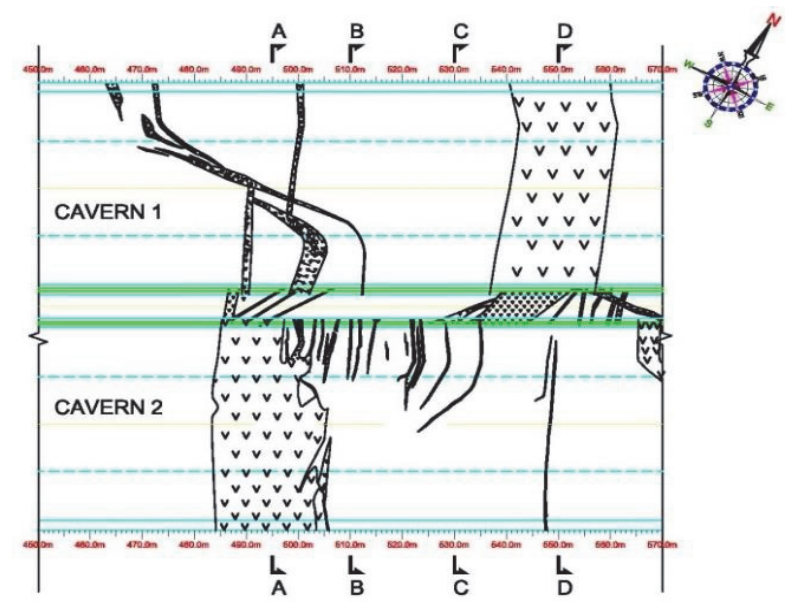

Fig. 3. Plan view of displaced segment

displaced segment along two caverns. To estimate the stability along pillar section four sections have been developed A, B C and D which are shown in Fig.3.

Geological face maps of wall and crown section were undertaken with an objective to describe the rock mass and associated discontinuities. In section $\mathrm{A}-\mathrm{A}$, dyke with fractured rock mass is observed in cavern 2 and the same is observed in cavern 1 in section D-D. The intersection of two dykes and its shifting was clearly seen through the face mapping of four cross sections. The longitudinal distance between sections are $20 \mathrm{~m}$ except section B-B is taken $15 \mathrm{~m}$ from section A-A. The joint interface properties were determined at field having persistence of $>6 \mathrm{~m}$, aperture size in the parent rock and dyke was varying in between $1 \mathrm{~mm}$ to $5 \mathrm{~mm}$. The spacing of the joints was observed to be $0.1 \mathrm{~m}$ to $0.5 \mathrm{~m}$ for both types of rock with dry excavation. The infilling material of joints in parent rock constituted of silty sand particles with calcareous coating, slightly altered and in highly fractured dyke rock, clayey to silty sand infilling were found with alteration along joint surfaces.

Hydro fracturing tests were conducted for in-situ stress measurement during the detailed study. The detailed analysis of the data indicated the following results for the virgin stress field (unit in $\mathrm{MPa}$ ):

$$
\begin{gathered}
S h=0.075+0.0575 z \\
S H=0.475+0.1025 z \\
S V=0.026 z
\end{gathered}
$$




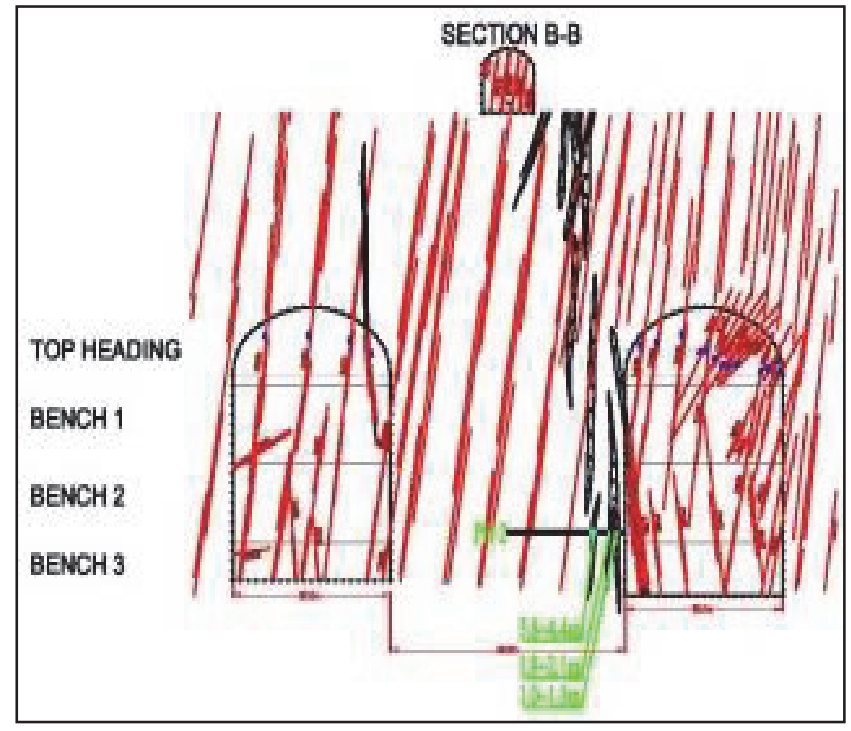

Section A-A

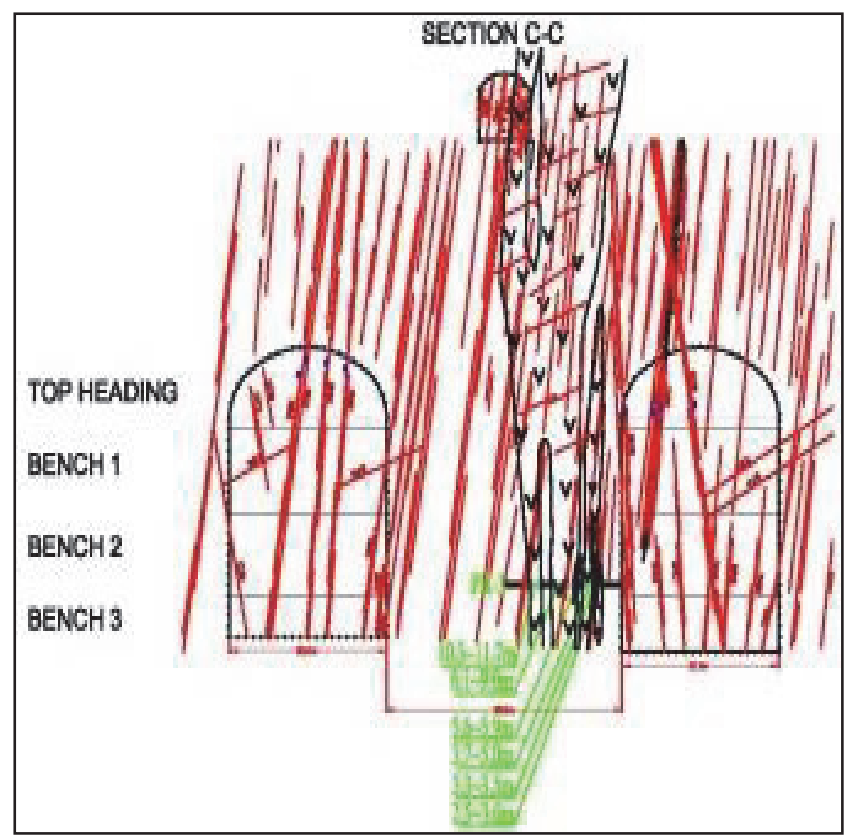

Section C-C

Fig. 4. Four sectional view of displaced segment

With Sh the minor horizontal stress, $\mathrm{SH}$ the major horizontal stress and SV the vertical stress and $\mathrm{z}$ the depth in meter below ground level. Mean orientation of the induced fractures suggests a direction of $\mathrm{N} 156^{\circ} \mathrm{E}( \pm 14 \mathrm{deg})$ for $\mathrm{SH}$. The horizontal to vertical stress ratio is about 2 for the minor horizontal stress $(\mathrm{Sh} / \mathrm{SV})$ and about 4 for the major horizontal stress $(\mathrm{SH} / \mathrm{SV})$ at the depth of the storage. The insitu stress measurements are shown in Table III.

The physical, mechanical and elastic properties of the rocks under consideration were determined from laboratory testing on intact rock samples. These tests include an Evaluation of uniaxial compressive strength $(\sigma c)$, Young's modulus (E), Poisson's ratio (v), unit weight $(\gamma)$, and tensile

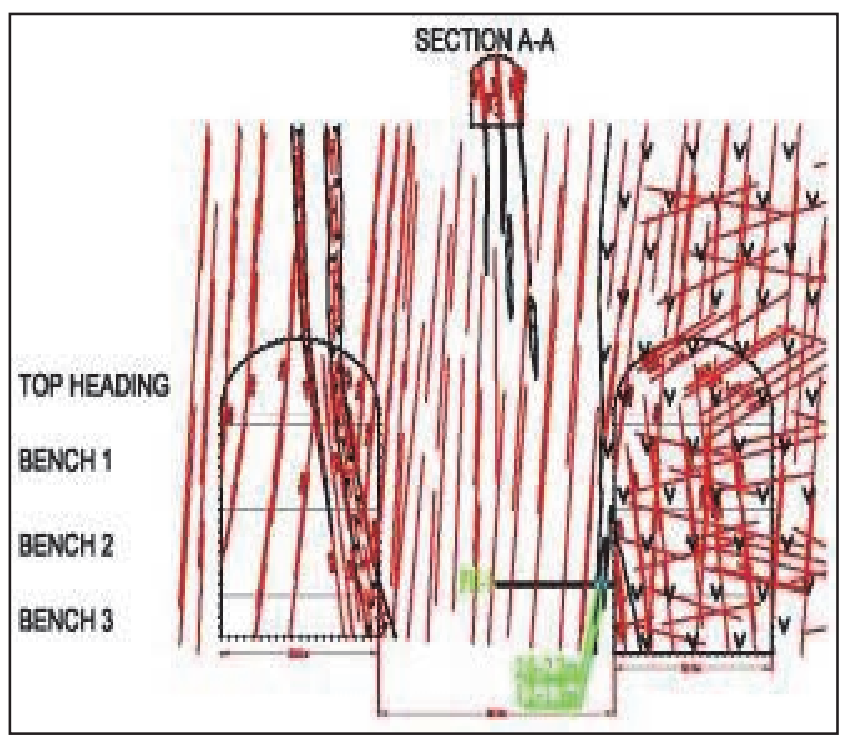

Section B-B

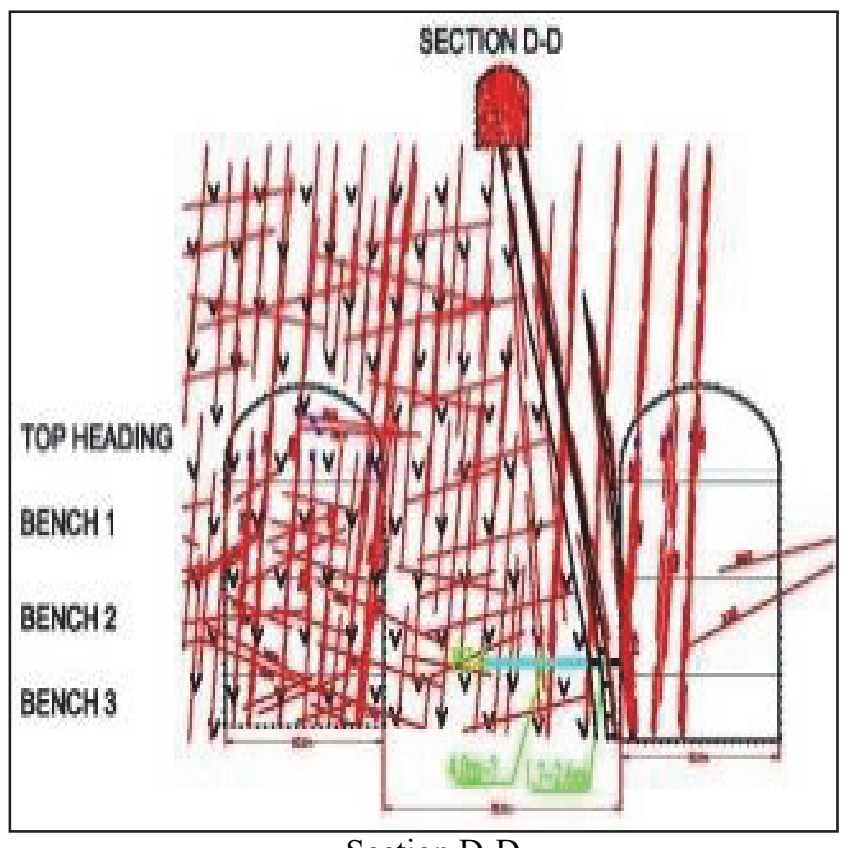

Section D-D

strength $(\sigma t)$. The intact rock mass properties of the project are shown in the following Table IV.

\section{ROCK MASS CLASSIFICATIONS}

Rock mass classification is important for quantitative descriptions of the rock mass quality. This in turn led to the development of many empirical designs involving rockmass. The rock classification essentially helps in providing premises on which rock mass can be divided. Based on these classification systems, quantitative assessment of supports system can be recommended. Amongst the various classification system, the $Q$ classification system has been utilized in this study. 
TABLE III. IN-SITU MEASUREMENTS

\begin{tabular}{|l|l|l|}
\hline \multicolumn{2}{|l|}{ Rock Stress at Cavern Roof } \\
\hline Property & Value & Remarks \\
\hline Vertical Stress (MPa) & 1.4 to & Rock cover varies from \\
& 2.2 & 50 to 80 \\
\hline Maximum Horizontal & 5.2 to & Rock cover varies from \\
Stress (MPa) & 8.3 & 50 to 80 \\
\hline Minimum Horizontal & 3.0 to & Rock cover varies from \\
Stress (MPa) & 4.7 & 50 to 80 \\
\hline
\end{tabular}

TABLE IV. INTACT ROCK PARAMETERS

\begin{tabular}{|l|l|}
\hline Property & Value \\
\hline Bulk Density (kN/m3) & $26.8 \pm 0.75$ \\
\hline UCS (MPa) & $134 \pm 43$ \\
\hline Tensile Strength $(\mathrm{MPa})$ & $6.7 \pm 2.4$ \\
\hline Young Modulus $(\mathrm{GPa})$ & $62 \pm 4.0$ \\
\hline Poisson's Ratio & 0.23 \\
\hline
\end{tabular}

Barton et al. (1974) developed the Q rock mass classification system. It is defined in terms of RQD, function of joint sets( Jn), discontinuity roughness(Jr), joint alteration $(\mathrm{Ja})$, water pressure $(\mathrm{Jw})$ and stress reduction factor (SRF). The Q-value is determined as:

$$
Q=\frac{R Q D}{J n} \times \frac{J r}{J a} \times \frac{J w}{S R F}
$$

According to the $\mathrm{Q}$ classification system, parent rock and dyke at the project site was considered as fair to good rockmass and poor rock mass, respectively, as tabulated in the Table V. Barton (2002) defined a new parameter, Q, to improve correlation among the engineering parameters.

$$
\begin{array}{r}
Q=\frac{R Q D}{J n} \times \frac{J r}{J a} \times \frac{J w}{S R F} \times \frac{Q c}{100} \\
Q c=Q \times \frac{\sigma c}{100}
\end{array}
$$

where, $\sigma_{\mathrm{c}}$ is uniaxial comprehensive strength of intact rock in $\mathrm{MPa}$.

Poor rock mass was observed in both caverns at section A-A and section D-D because of major dyke swarm at this locations and also these two section was considered as critical. As observed from Q ranges, poor rock mass has observed in the site location. So for analysis average Q-value for dyke intrusion and gneissic rockmass was considered.

\section{ESTIMATION OF ROCK MASS PROPERTIES}

\section{A. Properties of Gneiss and Dyke from $Q$}

The rock mass properties such as Mohr-Coulomb parameters, deformation modulus (Emass) and uniaxial compressive strength of rock mass ( $\sigma \mathrm{cmass})$ were calculated by means of empirical equations in accordance with the Q and Qc. The Mohr coulomb parameters cohesion (c) and angle of internal friction ( $\square$ ) are calculated based on the following equations proposed by Barton (2002) as follows:

$$
\begin{array}{r}
c(M P a)=C C=\frac{R Q D}{J n} \times \frac{1}{S R F} \times \frac{\sigma c}{100} \\
\phi=\mathrm{FC}=\tan ^{-1}\left(\frac{J r}{J a} \times J w\right)
\end{array}
$$

The deformation modulus $\left(\mathrm{E}_{\text {mass }}\right)$ and the uniaxial compressive strength of rock mass $\left(\sigma_{\mathrm{cm}}\right)$ were determined by the following set of equations proposed by Barton [2].

$$
\begin{aligned}
& \operatorname{Emass}(G P a)=10 Q c^{\frac{1}{3}} \\
& \sigma c m(M P a)=5 \gamma Q c
\end{aligned}
$$

\begin{tabular}{|c|c|c|c|c|}
\hline \multirow[b]{2}{*}{ 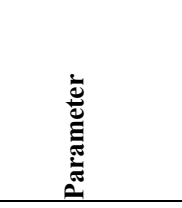 } & \multicolumn{2}{|c|}{ Parent rock } & \multicolumn{2}{|l|}{ Dyke } \\
\hline & 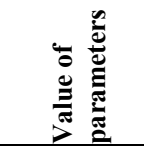 & 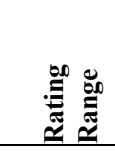 & 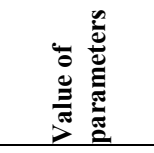 & 总 \\
\hline $\begin{array}{l}\text { Joint alteration } \\
\text { number (Ja) }\end{array}$ & $\begin{array}{l}\text { Infilling of } \\
\text { silty sand } \\
\text { with } \\
\text { partially } \\
\text { clay along } \\
\text { contact } \\
\text { boundary }\end{array}$ & 2 to 3 & $\begin{array}{l}\text { Infilling of } \\
\text { silty sand } \\
\text { (low friction } \\
\text { clay mineral } \\
\text { coating) }\end{array}$ & 3 to 4 \\
\hline $\begin{array}{l}\text { Joint water } \\
\text { reduction } \\
\text { factor }(\mathrm{Jw})\end{array}$ & $\begin{array}{l}\text { Dry } \\
\text { excavation } \\
\text { or minor } \\
\text { inflow }\end{array}$ & 1 & $\begin{array}{l}\text { Dry } \\
\text { excavation } \\
\text { or minor } \\
\text { inflow }\end{array}$ & 1.00 \\
\hline $\begin{array}{l}\text { Stress } \\
\text { reduction } \\
\text { factor (SRF) }\end{array}$ & $\begin{array}{l}\text { Medium } \\
\text { stress }\end{array}$ & 1 & $\begin{array}{l}\text { Medium } \\
\text { stress }\end{array}$ & 1.00 \\
\hline Q & Range & $\begin{array}{l}2.92 \text { to } \\
8.44\end{array}$ & Range & $\begin{array}{l}1.33 \text { to } \\
1.67\end{array}$ \\
\hline Q avg & & 5.68 & & 1.50 \\
\hline $\begin{array}{l}\text { Rock mass } \\
\text { Quality }\end{array}$ & \multicolumn{2}{|c|}{ Fair Rock to good rock } & \multicolumn{2}{|l|}{ Poor Rock } \\
\hline
\end{tabular}

where, $\gamma$ is the density of rock mass. The derived rock mass properties from the above set of equations are shown in Table VI.

TABLE V. ROCK MASS QUALITY INDEX

\section{B. Interface properties}

Joint stiffness is not an easily measured or well-known parameter. Methods of estimating joint stiffness have been derived based on the deformation properties of the rock mass and the intact rock. The joint normal stiffness and shear stiffness is obtained from studies performed by Barton, 1972.

The infill material is silty sand with clay and angle of friction of the material is $20^{\circ}$. Since the thickness of infill material is less, it is assumed that the behavior of interface is governed by stiffness of dyke rock mass.

The properties of rock mass and interfaces are presented in Table VI and the same parameters are used for numerical modelling. 
TABLE VI. PROPERTIES OF ROCK MASS

\begin{tabular}{|c|c|c|c|}
\hline Parameter & Units & Gneiss & Dolerite Dyke \\
\hline Average' Q' value & & 5.68 & 1.5 \\
\hline Intact rock strength, $\sigma c i$ & $\mathrm{MPa}$ & 134 & 91 \\
\hline $\begin{array}{l}\text { Tensile strength of Intact } \\
\text { rock mass, Ti }\end{array}$ & $\mathrm{MPa}$ & 6.7 & 4.3 \\
\hline Mean joint spacing & $\mathrm{m}$ & 0.15 & 0.1 \\
\hline Poisson's Ratio, v & & 0.23 & 0.23 \\
\hline Cohesive strength, $\mathrm{C}$ & $\mathrm{MPa}$ & 11.54 & 3.24 \\
\hline Angle of internal friction, $\phi$ & & 26 & 20 \\
\hline $\begin{array}{l}\text { Deformation modulus of } \\
\text { rock mass, Erm }\end{array}$ & $\mathrm{MPa}$ & 17920 & 10410 \\
\hline $\begin{array}{l}\text { Shear modulus of rock mass, } \\
\text { Grm }\end{array}$ & $\mathrm{MPa}$ & 7280 & 4230 \\
\hline $\begin{array}{l}\text { Normal stiffness of } \\
\text { interface, } \mathrm{Kn}\end{array}$ & $\mathrm{MPa} / \mathrm{m}$ & 168090 & 126890 \\
\hline $\begin{array}{l}\text { Shear stiffness of interface, } \\
\text { Ks }\end{array}$ & $\mathrm{MPa} / \mathrm{m}$ & 68330 & 51580 \\
\hline
\end{tabular}

\section{TUNNEL SUPPORTS AND STABILITY ANALYSIS}

\section{A. Cavern supports}

The tunnel supports are defined in accordance with the recommendations in Q system. Barton suggested supports for different rock mass classes in the Q system [5]. As noted earlier, according to the $\mathrm{Q}$ system, parent rock and dyke are fair and poor rock masses, respectively. A summary of the estimated supports using the Q-system are presented in Table VII.

\section{B. Numerical analysis by FLAC}

The objective of cavern design is to guarantee its sufficient stability and serviceability during stage wise excavation. In order estimate the displacement, extent of plastic zone and stability of pillar, a two-dimensional finite difference software, FLAC 2D, was used. The rock mass properties assumed from the estimated values are presented in Section IV.

The Mohr-coulomb failure criterion was used to identify elements undergoing yielding and the plastic zones of rock masses in the vicinity of tunnel perimeter. Elasto-Plastic failure strength parameters were used in the analysis. Average in-situ stresses were generated by keeping the insitu stress value of 3 . In order to simulate the excavation process with in parent rock and dyke, different finite element models were generated using the same mesh and tunnel geometry, but different material properties.

The following sections running through gneiss and dolerite dyke were considered and accordingly numerical models were prepared with different geological configurations as shown in Fig. 5: Section A-A, Section BB, Section C-C and Section D-D.

The contact between the dyke and parent rock was found to be weak. In order to simulate this condition, interfaces were introduced in the model.

TABLE VII. SUPPORT CLASSES

\begin{tabular}{|c|c|c|}
\hline Q system & Gneiss & Dolerite Dyke \\
\hline Qavg & 5.68 & 1.50 \\
\hline Rock Mass Quality & $\begin{array}{l}\text { Fair Rock to } \\
\text { good rock }\end{array}$ & Poor Rock \\
\hline ESR & 1.2 & 1.2 \\
\hline De (roof) & 16.67 & 16.67 \\
\hline De (wall) & 24 & 24 \\
\hline $\begin{array}{l}\text { Roof Support } \\
\text { Pressure P roof }\end{array}$ & $0.11-0.128$ & $0.12-0.22$ \\
\hline $\begin{array}{l}\text { Wall Support } \\
\text { Pressure P wall }\end{array}$ & $0.08-0.094$ & $0.09-0.16$ \\
\hline Roof Support & $\begin{array}{l}\text { Steel fibre } \\
\text { reinforced shotcrete } \\
\text { of } 6-9 \mathrm{~cm} \text { and } \\
\text { bolting } \\
, 4.5 \mathrm{~m} \text { long and } \\
\text { spaced } 1.8-2.2 \mathrm{~m}\end{array}$ & $\begin{array}{l}\text { Steel fibre reinforced } \\
\text { shotcrete of } 10-11 \\
\mathrm{~cm} \text { and bolting } \\
, 4.5 \mathrm{~m} \text { long and } \\
\text { spaced } 1.8-2.0 \mathrm{~m}\end{array}$ \\
\hline Wall Support & $\begin{array}{l}\text { Steel fibre } \\
\text { reinforced shotcrete } \\
\text { of } 11- \\
14 \mathrm{~cm} \text { and bolting } \\
, 6 \mathrm{~m} \text { long and spaced } \\
1.8- \\
2.2 \mathrm{~m}\end{array}$ & $\begin{array}{l}\text { Steel fibre reinforced } \\
\text { shotcrete of } 14-15 \\
\mathrm{~cm} \text { and bolting } \\
, 6 \mathrm{~m} \text { long and } \\
\text { spaced } 1.8-2.0 \mathrm{~m}\end{array}$ \\
\hline
\end{tabular}

From the geological mapping, various dyke intrusions were identified. At section A-A asmalldykeintrusionof5m thickness was found to pass through cavern-1 cutting across the crown and the right wall. Additionally, cavern 2 was excavated in fractured dyke rock. In sections B-B and C-C, dyke intrusion is observed in pillar location oriented near to cavern 2 . In section D-D, it was observed that the cavern 1 wasexcavatedindykerockinandcavern 2 wasexcavatedin the parent rock mass. The thickness of dyke intrusion varied in each section. The three-dimensional interaction of dyke and parent rock is beyond the scope of this paper.

An outline of the steps followed for performing a numerical analysis is presented below:

1. Creating numerical model including dyke interfaces and assigning material properties.

2. Applying boundary conditions and initial conditions

3. Developing geostatic stress state condition and setting initial displacements to zero.

4. Excavating the top heading and installing supports, similar for bench excavation.

5. Checking the adequacy of support and tunnel stability. 


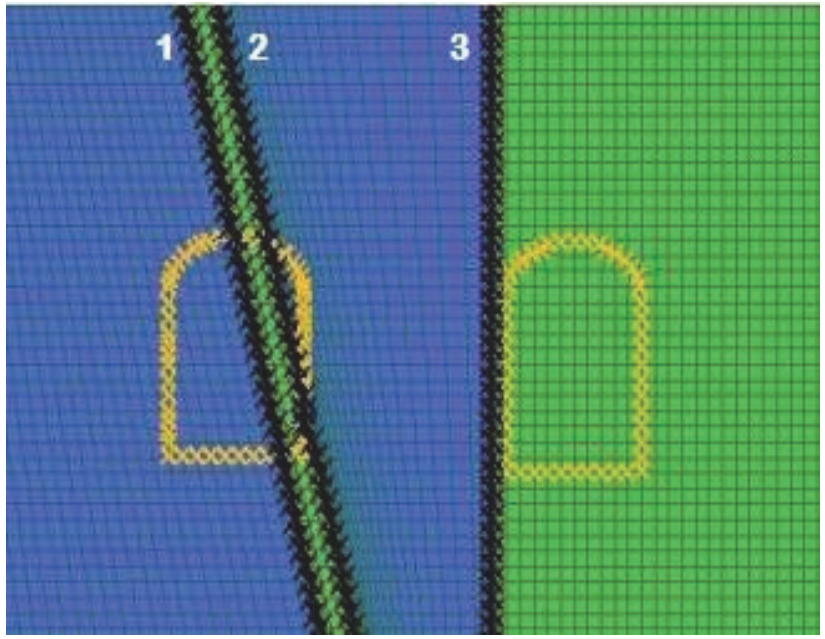

Section A-A

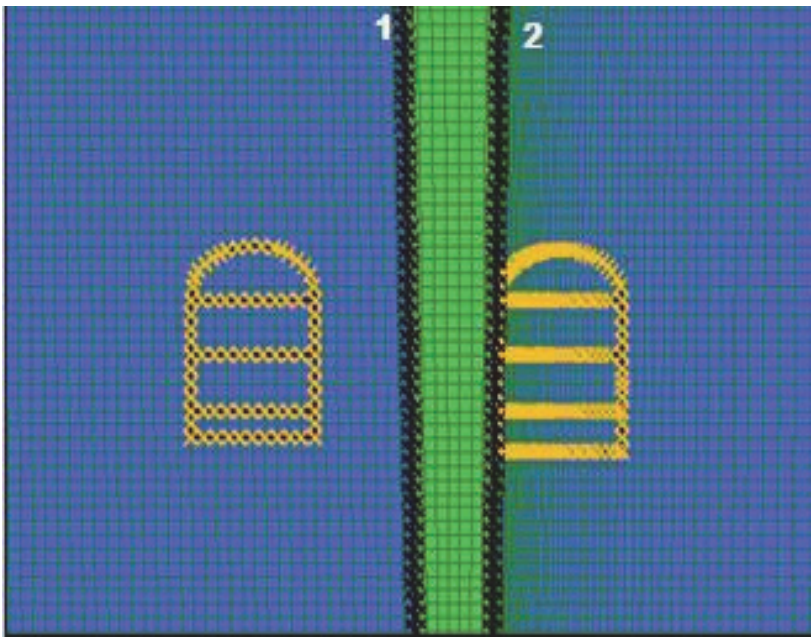

Section C-C

Parentrock

Dyke

Fig. 5 Sections considered in numerical modelling

The tunnel was simultaneously excavated in sequence which was considered similar in both the caverns. At first stage top heading excavated followed by supports installation was carried out. In the same way, excavation of benching and supports installation has been analyzed simultaneously in both caverns. No relaxation of rock mass before installation of supports was considered in the analysis as the tunneling method assumed was Norwegian method of tunneling (NMT).

The support elements consisted of rock bolts and fibercrete/shotcrete, as designed through the empirical methods. The properties of support elements, such as bolt length, bolt patterns and thickness of fibercrete / shotcrete are similar to those adopted in the empirical methods.

The mechanical properties of supports are tabulated in Table-VIII. The bond shear stiffness and the bond strength for fully grouted rock bolt were calculated based the theory given in the ITASCA manual.

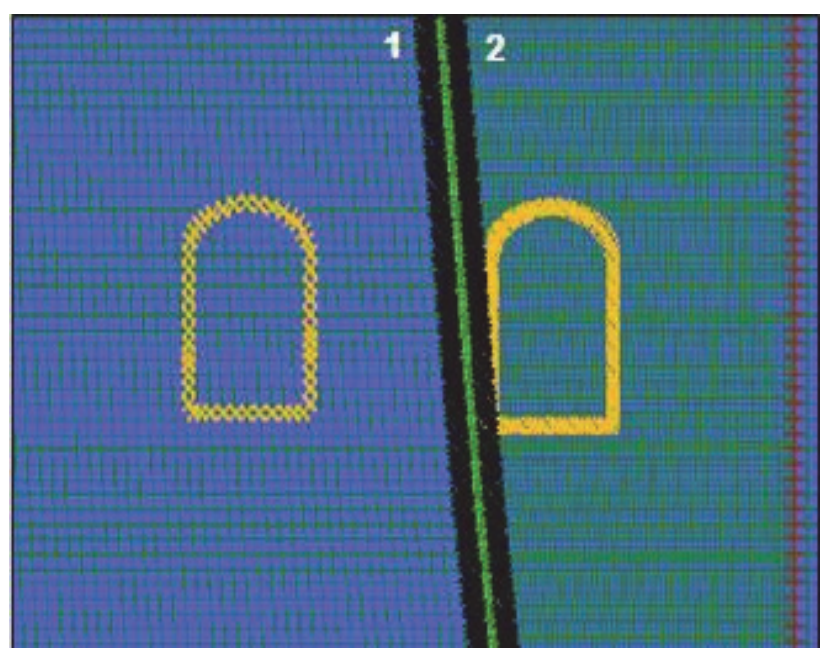

Section B-B

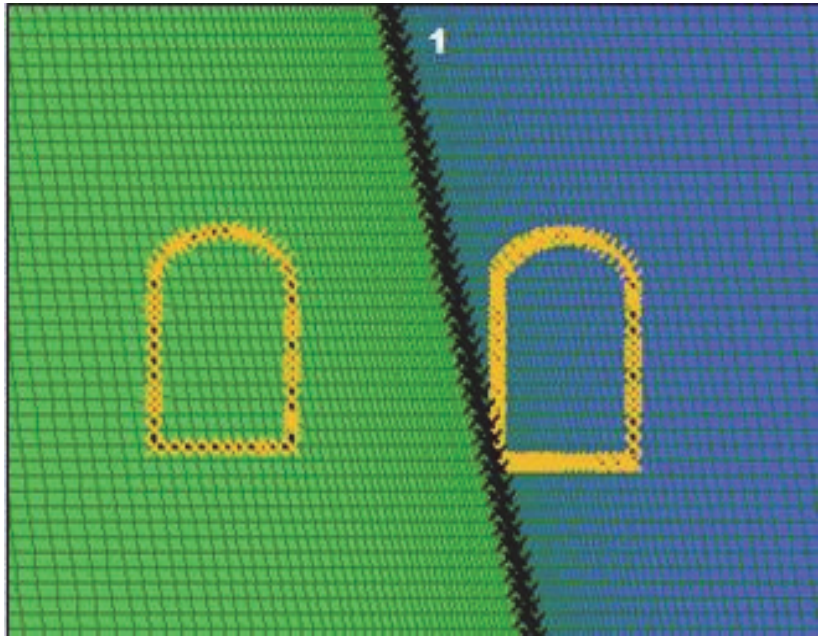

Section D-D

Dyke-Interface

\section{Results and discussion}

Generally, stability of tunnel is evaluated by stress distribution and ground movement around tunnel openings. The factors influencing the stability of a cavern and pillar are initial stress conditions, influence of dyke intrusion, strength and stiffness of rock mass and properties of infill materials. The parameters considered to study the cavern stability are deformations, stresses around the cavern, displacements.

In order to predict the stress variation, maximum displacement, the principal stresses and deformation at crown, left side \& right side wall of each cavern has observed before and after supports and presented in Table IX to Table XII.

For supported cases, total displacements and plastic zones around the openings for the different sections were presented inFig. 6 and Fig.7 respectively. 
TABLE VIII: PROPERTIES OF RECOMMENDED SUPPORTS

\begin{tabular}{|l|l|l|l|}
\hline $\begin{array}{l}\text { Rock Bolt } \\
\text { Property }\end{array}$ & Units & $\begin{array}{l}\text { Parent rock } \\
\text { mass }\end{array}$ & Dyke \\
\hline Type & Fully Grouted Rock Bolt \\
\hline Diameter & $\mathrm{m}$ & 25 & 25 \\
\hline length & $\mathrm{m}$ & $5 \& 6$ & 5 \& 6 \\
\hline Bolt Modulus & $\mathrm{MPa}$ & 200000 & 200000 \\
\hline Tensile capacity & $\mathrm{MN}$ & 0.2 & 0.2 \\
\hline $\begin{array}{l}\text { Bond shear } \\
\text { stiffness }\end{array}$ & $\mathrm{MN} / \mathrm{m} / \mathrm{m}$ & 11354 & 6597 \\
\hline Bond strength & $\mathrm{MN} / \mathrm{m}$ & 0.596 & 0.341 \\
\hline $\begin{array}{l}\text { Shotcrete } \\
\text { Property }\end{array}$ & Units & $\begin{array}{l}\text { Parent rock } \\
\text { mass }\end{array}$ & Dyke \\
\hline Type & Steel Fibre Reinforced shotcrete \\
\hline Young's Modulus & $\mathrm{MPa}$ & 27386 & 27386 \\
\hline Poisson's Ratio & \multicolumn{4}{|l|}{} \\
\hline $\begin{array}{l}\text { Thickness } \\
\text { of shotcrete }\end{array}$ & $\mathrm{m}$ & 0.2 & 0.2 \\
\hline
\end{tabular}

\section{Results and discussion}

Generally, stability of tunnel is evaluated by stress distribution and ground movement around tunnel openings. The factors influencing the stability of a cavern and pillar are initial stress conditions, influence of dyke intrusion, strength and stiffness of rock mass and properties of infill materials. The parameters considered to study the cavern stability are deformations, stresses around the cavern, displacements. In order to predict the stress variation, maximum displacement, the principal stresses and deformation at crown, left side \& right side wall of each cavern has observed before and after supports and presented in Table IX to Table XII. For supported cases, total displacements and plastic zones around the openings for the different sections were presented inFig.6 and Fig.7 respectively.

The results indicated that there was a marginal increase of stress after supporting due to the control of displacements by provision of supports. The horizontal displacements were found to be higher than vertical due to the higher horizontal stress existing in the area. In section A-A, the dyke of width $5 \mathrm{~m}$ is passing through the cavern 1 and cavern. It is observed from Table IX and Fig. 6, that the cavern 2 has experienced more horizontal displacements due to the presence of dyke. Also due to more in-situ stress ratio, horizontal displacements are more when compared to the vertical displacements.

In section B-B and section C-C, the dyke of width $5 \mathrm{~m}$ and $12 \mathrm{~m}$ respectively is passing between the cavern 1 and cavern 2 in the pillar portion. It was observed from Table X and Fig. 6, that the cavern 2 in section $\mathrm{C}-\mathrm{C}$ has experienced more horizontal displacements because of the presence of dyke closer to cavern. Also due to more in-situ stress ratio, horizontal displacements were more when compared to the vertical displacements.
It was observed from Table XI and Fig. 6, that the cavern1 has experienced more horizontal displacements due to the presence of dyke in section D-D. It was noted that depending on the orientation of dyke, interface displacements were varying. The total displacement behavior and extent of plastic zone after support are given in Fig. 6 and Fig. 7 respectively

TABLE IX. STRESSES AND DisPlacement BEFORE AND AFTER SuPPORTS IN SECTION A-A

\begin{tabular}{|c|c|c|c|c|c|c|}
\hline \multirow[b]{2}{*}{ • } & \multirow[b]{2}{*}{ 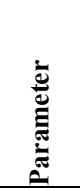 } & \multirow[b]{2}{*}{$\stackrel{\mathscr{\Xi}}{\stackrel{\Xi}{\Xi}}$} & \multicolumn{2}{|c|}{ Cavern 1} & \multicolumn{2}{|c|}{ Cavern 2} \\
\hline & & & 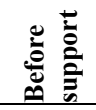 & 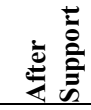 & 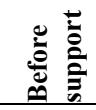 & 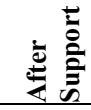 \\
\hline \multirow{4}{*}{ 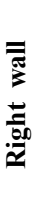 } & $\sigma 1$ & $\mathrm{MPa}$ & 2.76 & 2.93 & 0.59 & 0.68 \\
\hline & $\sigma 3$ & $\mathrm{MPa}$ & 0.01 & 0.05 & 0.04 & 0.02 \\
\hline & $\mathrm{x}$-disp & $\mathrm{mm}$ & 10.54 & 8.63 & 30.84 & 29.30 \\
\hline & $y$-disp & $\mathrm{mm}$ & 1.09 & 0.92 & 0.16 & 0.14 \\
\hline \multirow{4}{*}{ 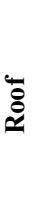 } & $\sigma 1$ & $\mathrm{MPa}$ & 12.69 & 13.10 & 11.25 & 11.92 \\
\hline & $\sigma 3$ & $\mathrm{MPa}$ & 1.72 & 1.90 & 0.95 & 1.28 \\
\hline & $\mathrm{x}$-disp & $\mathrm{mm}$ & 4.13 & 3.60 & 4.24 & 4.56 \\
\hline & $y$-disp & $\mathrm{mm}$ & 2.38 & 2.11 & 3.91 & 3.11 \\
\hline \multirow{4}{*}{ 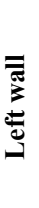 } & $\sigma 1$ & $\mathrm{MPa}$ & 0.87 & 0.95 & 3.63 & 3.52 \\
\hline & $\sigma 3$ & $\mathrm{MPa}$ & 0.19 & 0.21 & 0.06 & 0.08 \\
\hline & $\mathrm{x}$-disp & $\mathrm{mm}$ & 17.82 & 16.85 & 16.13 & 13.25 \\
\hline & $y$-disp & $\mathrm{mm}$ & 0.39 & 0.00 & 0.28 & 0.36 \\
\hline
\end{tabular}

TABLE X. STRESSES AND DisPlaCEMENT Before AND AFter SuPPORTS IN SECTION B-B

\begin{tabular}{|c|c|c|c|c|c|c|}
\hline \multirow[b]{2}{*}{ لِّ } & \multirow[b]{2}{*}{ 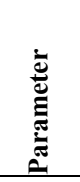 } & \multirow[b]{2}{*}{$\stackrel{\mathscr{\Xi}}{\stackrel{\varrho}{\varrho}}$} & \multicolumn{2}{|c|}{ Cavern 1} & \multicolumn{2}{|c|}{ Cavern 2} \\
\hline & & & 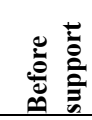 & 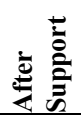 & 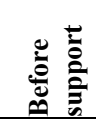 & 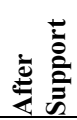 \\
\hline \multirow{4}{*}{ 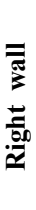 } & $\sigma 1$ & $\mathrm{MPa}$ & 2.84 & 2.77 & 0.34 & 0.44 \\
\hline & $\sigma 3$ & Mpa & 0.02 & 0.02 & 0.00 & 0.01 \\
\hline & $\mathrm{x}$-disp & $\mathrm{mm}$ & 6.89 & 6.60 & 19.28 & 17.97 \\
\hline & $y$-disp & $\mathrm{mm}$ & 0.61 & 0.17 & 0.39 & 0.23 \\
\hline \multirow{4}{*}{ 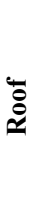 } & $\sigma 1$ & $\mathrm{MPa}$ & 19.72 & 19.55 & 21.49 & 21.19 \\
\hline & $\sigma 3$ & Mpa & 0.87 & 0.96 & 0.53 & 0.66 \\
\hline & $\mathrm{x}$-disp & $\mathrm{mm}$ & 2.86 & 3.04 & 2.46 & 2.65 \\
\hline & $y$-disp & $\mathrm{mm}$ & 1.37 & 0.87 & 1.25 & 0.66 \\
\hline \multirow{4}{*}{ 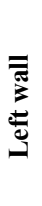 } & $\sigma 1$ & $\mathrm{MPa}$ & 1.07 & 1.22 & 3.45 & 3.44 \\
\hline & $\sigma 3$ & Mpa & 0.06 & 0.04 & 0.03 & 0.08 \\
\hline & $\mathrm{x}$-disp & $\mathrm{mm}$ & 17.93 & 17.60 & 16.40 & 14.01 \\
\hline & $y$-disp & $\mathrm{mm}$ & 0.37 & 0.07 & 0.20 & 0.22 \\
\hline
\end{tabular}



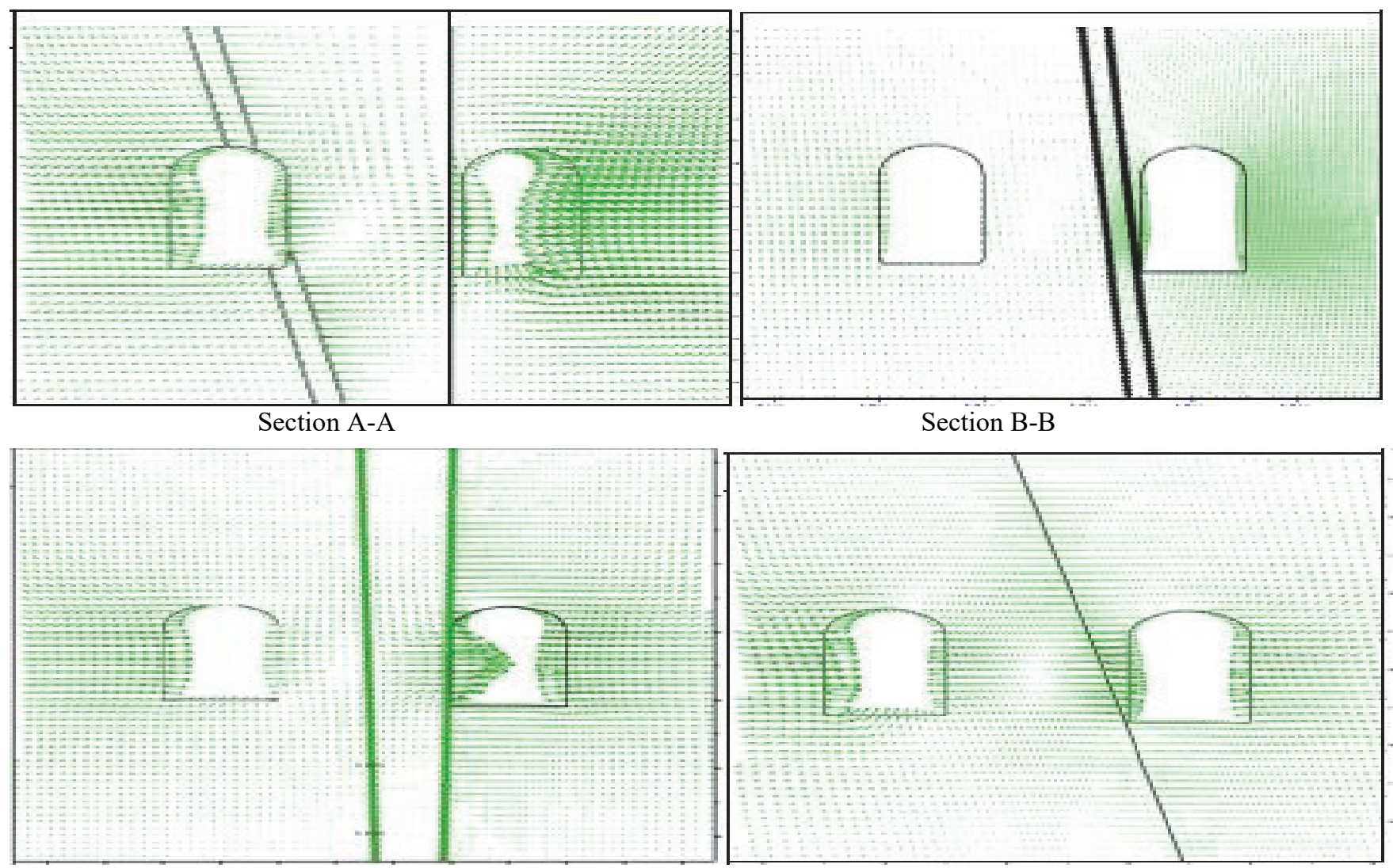

Section C-C

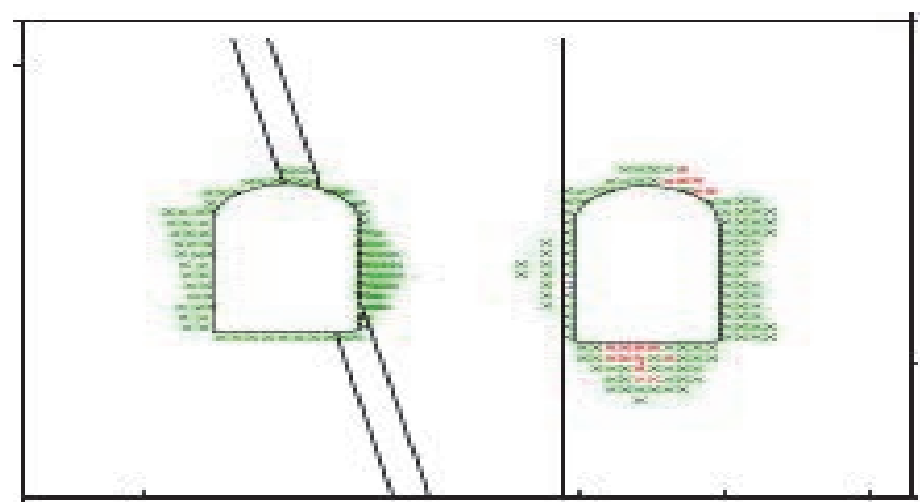

Section D-D

Section A-A

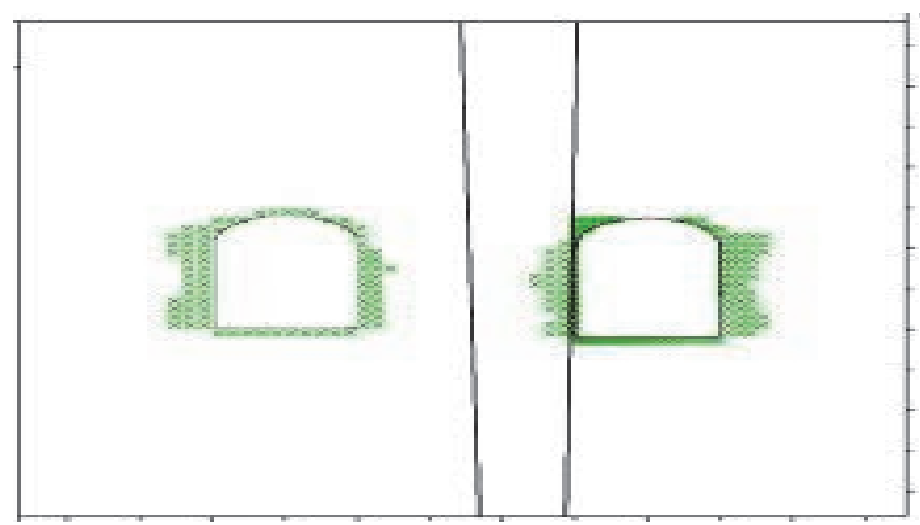

Section C-C

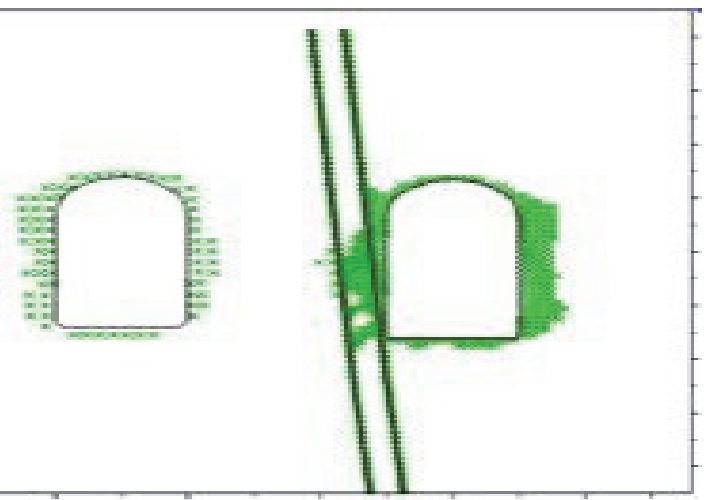

Section B-B

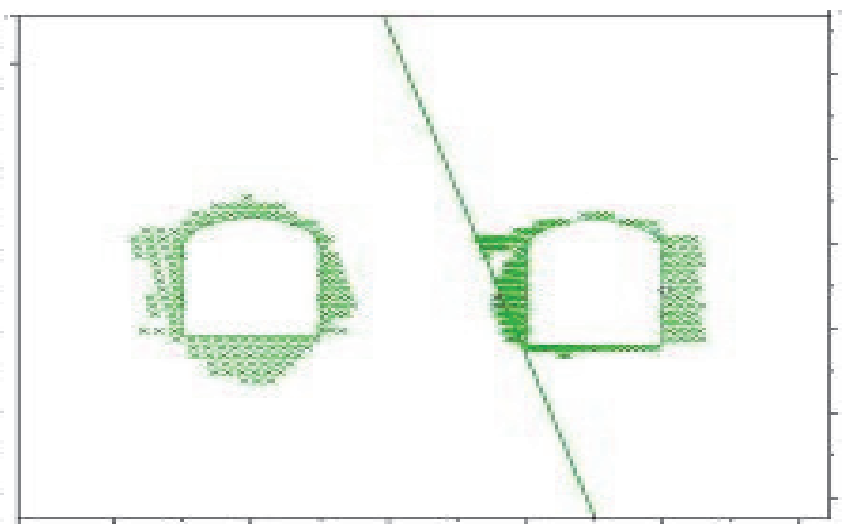

Section D-D

Fig. 6. Total displacement profiles 
Interfaces behavior was analyzed by observing the normal and shear displacements which were presented in Table XIII.

TABLE XI. STRESSES AND DisPlaCEMENT BEFORE AND AFTER SUPPORTS in SECTION C-C

\begin{tabular}{|c|c|c|c|c|c|c|}
\hline \multirow[b]{2}{*}{. } & \multirow[b]{2}{*}{ : } & \multirow[b]{2}{*}{$\stackrel{\mathscr{\Xi}}{\Xi}$} & \multicolumn{2}{|c|}{ Cavern 1} & \multicolumn{2}{|c|}{ Cavern 2} \\
\hline & & & 竞 & 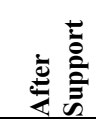 & 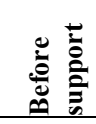 & 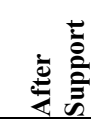 \\
\hline \multirow{4}{*}{$\begin{array}{l}\bar{\sigma} \\
\bar{z} \\
\bar{z} \\
\bar{z}\end{array}$} & $\sigma 1$ & $\mathrm{MPa}$ & 2.11 & 2.29 & 0.83 & 0.68 \\
\hline & $\sigma 3$ & $\mathrm{MPa}$ & 0.02 & 0.02 & 0.01 & 0.02 \\
\hline & $\mathrm{x}$-disp & $\mathrm{mm}$ & 7.71 & 7.96 & 19.51 & 16.45 \\
\hline & $y$-disp & $\mathrm{mm}$ & 0.33 & 0.29 & 0.21 & 0.09 \\
\hline \multirow{4}{*}{ 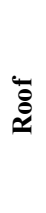 } & $\sigma 1$ & $\mathrm{MPa}$ & 16.51 & 16.39 & 17.03 & 16.90 \\
\hline & $\sigma 3$ & $\mathrm{MPa}$ & 1.19 & 1.25 & 1.45 & 1.47 \\
\hline & $\mathrm{x}$-disp & $\mathrm{mm}$ & 2.81 & 2.80 & 2.33 & 2.32 \\
\hline & $y$-disp & $\mathrm{mm}$ & 0.94 & 0.90 & 0.67 & 0.63 \\
\hline \multirow{4}{*}{ 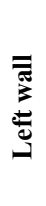 } & $\sigma 1$ & $\mathrm{MPa}$ & 0.66 & 0.60 & 1.27 & 1.29 \\
\hline & $\sigma 3$ & $\mathrm{MPa}$ & 0.02 & 0.05 & 0.04 & 0.08 \\
\hline & $\mathrm{x}$-disp & $\mathrm{mm}$ & 16.53 & 15.28 & 36.10 & 26.26 \\
\hline & $y$-disp & $\mathrm{mm}$ & 0.67 & 0.44 & 0.57 & 0.21 \\
\hline
\end{tabular}

TABLE XII. STRESSES AND DISPLACEMENT BEFORE AND AFTER SUPPORTS IN SECTION D-D

\begin{tabular}{|c|c|c|c|c|c|c|}
\hline \multirow[b]{2}{*}{ 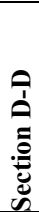 } & \multirow[b]{2}{*}{ 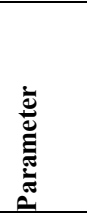 } & \multirow[b]{2}{*}{$\stackrel{\mathscr{B}}{\mathbf{S}}$} & \multicolumn{2}{|c|}{ Cavern 1} & \multicolumn{2}{|c|}{ Cavern 2} \\
\hline & & & 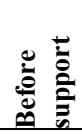 & 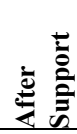 & 窇 & 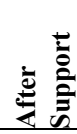 \\
\hline \multirow{4}{*}{ 焉 } & $\sigma 1$ & $\mathrm{MPa}$ & 2.59 & 2.45 & 0.41 & 1.16 \\
\hline & $\sigma 3$ & $\mathrm{MPa}$ & 0.07 & 0.03 & 0.02 & 0.00 \\
\hline & $\mathrm{x}$-disp & $\mathrm{mm}$ & 21.95 & 13.94 & 22.63 & 17.56 \\
\hline & $y$-disp & $\mathrm{mm}$ & 0.96 & 0.32 & 1.48 & 0.40 \\
\hline \multirow{4}{*}{ 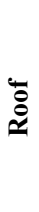 } & $\sigma 1$ & $\mathrm{MPa}$ & 10.96 & 11.61 & 18.5 & 18.53 \\
\hline & $\sigma 3$ & $\mathrm{MPa}$ & 0.80 & 1.12 & 1.52 & 1.62 \\
\hline & $\mathrm{x}$-disp & $\mathrm{mm}$ & 4.57 & 4.70 & 2.29 & 2.10 \\
\hline & $y$-disp & $\mathrm{mm}$ & 4.77 & 3.94 & 1.62 & 1.55 \\
\hline \multirow{4}{*}{ 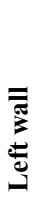 } & $\sigma 1$ & $\mathrm{MPa}$ & 0.32 & 0.94 & 1.85 & 3.01 \\
\hline & $\sigma 3$ & $\mathrm{MPa}$ & 0.04 & 0.06 & 0.11 & 0.16 \\
\hline & $\mathrm{x}$-disp & $\mathrm{mm}$ & 37.56 & 30.12 & 20.47 & 14.10 \\
\hline & $y$-disp & $\mathrm{mm}$ & 1.35 & 0.17 & 0.06 & 0.18 \\
\hline
\end{tabular}

In section A-A, before support installation, maximum shear displacement was observed at interface 2 as the interfaces were intersecting with the cavern 1 . However, the shear displacement has been drastically reduced after support.

TABLE XIII. SHEAR AND NORMAL DISPlaCEMENTS AT THE INTERFACES

\begin{tabular}{|c|c|c|c|c|c|}
\hline \multirow[b]{2}{*}{.ֶّ } & \multirow[b]{2}{*}{ 异 } & \multicolumn{2}{|c|}{$\begin{array}{l}\text { Max Shear } \\
\text { Displacement }(\mathrm{mm})\end{array}$} & \multicolumn{2}{|c|}{$\begin{array}{l}\text { Max Normal } \\
\text { Displacement (mm) }\end{array}$} \\
\hline & & 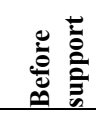 & 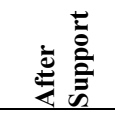 & 节 & 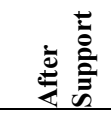 \\
\hline \multirow{3}{*}{$\sum_{4}^{4}$} & Interface 1 & 3.26 & 3.12 & 3.79 & 3.45 \\
\hline & Interface 2 & 8.43 & 2.45 & 4.56 & 4.53 \\
\hline & Interface 3 & 2.77 & 2.59 & 9.98 & 8.72 \\
\hline \multirow{2}{*}{$\stackrel{\oplus}{\oplus}$} & Interface 1 & 2.58 & 2.51 & 6.65 & 6.72 \\
\hline & Interface 2 & 4.03 & 3.38 & 13.20 & 11.75 \\
\hline \multirow{2}{*}{ U. } & Interface 1 & 2.55 & 2.56 & 1.58 & 1.56 \\
\hline & Interface 2 & 2.88 & 2.88 & 30.76 & 24.28 \\
\hline อ̀ & Interface 1 & 5.21 & 4.98 & 13.05 & 10.90 \\
\hline
\end{tabular}

installation which illustrates the effectiveness of the support. There is no significant change in shear displacement at the remaining interfaces before and after installation of support as the horizontal in-situ stresses were more which acts as a normal stress on interface and moreover interface was almost orthogonal to the direction of the major principle stress. In section $\mathrm{C}-\mathrm{C}$, maximum normal displacement was observedatinterface2sincetheboundaryofinterfaceisnear to the excavation line. In case other interfaces, the same pattern of normal displacements has been observed as in section C-C.

The adequacy of support system was evaluated by analyzing the formation of plastic zone around the caverns. It can be seen from Fig. 7 that there is no overlap between the plastic zones from two caverns. Also there is no significant projection of plastic zone and tensile failure zone beyond $2.5 \mathrm{~m}$ from the tunnel edge. Some orientation of plastic zone was observed along the interface of dyke and tunnel opening.

\section{CONCLUSIONS}

The paper presented a design approach to arrive at the support system for a cavern having dyke intrusions. According to the results obtained from the numerical analysis, the pillar at all cross-sections is stable with the dyke intrusion in between caverns. The stability is due the reasons that model is having more horizontal stress (K0 of 3 ) and the tight joints. Since the horizontal stress acts as a normal stress on the dyke interfaces, more shear stress is required to produce the shear displacements along the interface. The joint interface between the gneiss and the dyke is assumed as the tight joint because as per the geology the joint aperture is less $(2 \mathrm{~mm}-4 \mathrm{~mm})$ and the joint in filling material is stated silty sand particles with calcareous coating predominantly. However, the numerical analysis showed that there was a considerable decrease in both the number of yielded elements and the size of plastic zone around the 
tunnel after installation of the support elements.

During the site execution, localized failures were observed at dyke intrusion and tunnel opening interface. This was not reflected in the numerical model. The crystallized cubical structure of dyke caused the above movements. This phenomenon was not possible to simulate due to lack of yield criteria in numerical modeling catering such behavior. The study also revealed the sensitivity of the interface properties which plays an important role in development of stresses.

\section{REFERENCES}

[1] S.C. Bandis, A.C. Lumsden and N.R. Barton. "Fundamentals of Rock Joint Deformation", Int.J. Rock Mech. Min. Sci. \& Geomech. Abstr., 20(6)., 249- 268(1983).

[2] N. Barton. "The shear strength of rock and rock joints", Int.J. Rock Mech. Min. Sci. \& Geomech. Abstr., 13., 255-279(1976).

[3] Zulfu Gurocak, Pranshoo Solanki and Musharraf M. Zaman. "Empirical and numerical analyses of support requirements for a diversion tunnel at the Boztepe dam site, eastern Turkey", Engineering Geology, 91. 194-208(2007).

[4] Underground space technologies, an edited book by EIL

[5] N. Barton. And E. Grimstad, "An illustrated guide to the Qsystem following 40 years use in tunnelling", Page 3 of downloads: www.nickbarton.com, PP 4., 2014.

[6] ITASCA, Flac 7.0 User manual 